\title{
Inoculum production of arbuscular mycorrhizal fungi native to soils under different forest covers ${ }^{1}$
}

\author{
Renata Soares dos Santos ${ }^{2 *}$, Joilson Silva Ferreira ${ }^{3}$, Rafael Nogueira Scoriza
}

10.1590/0034-737X201764020013

\begin{abstract}
The low natural fertility of Brazilian soils requires the use of inoculants that facilitate the absorption of nutrients by plants. Arbuscular mycorrhizal fungi such as obligatory biotrophics of active roots perform this function, but access to this resource is limited by the difficulty in producing inoculants. The objective of this study was to investigate the production of AMF inoculants native of soils under different forest covers in Vitória da Conquista, BA, by means of spore quantification, colonization rate and species identification. For this purpose, soils were collected from sites under Mata Nativa (native forest) and plantations of Madeira Nova (Pterogyne nitens) and Eucalyptus, placed into separate $500 \mathrm{~mL}$ disposable cups with seeds of Brachiaria sp. and cultivated for five months. Spores were quantified and the AMF species identified in the control soil (without brachiaria) and in the cups cultivated with brachiaria at each month. From the first month, the colonization rate of brachiaria roots was evaluated. The inoculants produced showed differences in the number of spores and species, in the AMF species identified, and in the root colonization rate as a function of the forest cover. Thus, considering the increase in the number of spores, species and colonization over time, the inoculant produced from the soil under native forest was more promising for utilization.
\end{abstract}

Keywords: symbiont; trap culture; forest recovery.

\section{RESUMO}

\section{Produção de inóculos de fungos micorrízicos arbusculares nativos de solos sob diferentes coberturas florestais}

A baixa fertilidade natural dos solos brasileiros requer o uso de inoculantes que facilitem a absorção de nutrientes pelas plantas. Os fungos micorrízicos arbusculares como biotróficos obrigatórios de raízes ativas desempenham esta função, porém o acesso a este recurso é limitado pela dificuldade na produção de inoculantes. Com isso, o objetivo deste trabalho foi avaliar a produção de inoculantes de FMAs nativos de solos sob diferentes coberturas florestais em Vitória da Conquista - BA, através da quantificação de esporos, taxa de colonização e identificação de espécies. Para isso, foram coletados solos nas coberturas florestais de Mata Nativa e em plantios de Madeira Nova e Eucalipto, colocados separadamente em vasos com braquiária e cultivados por cinco meses. No solo testemunha e a cada mês foram quantificados os esporos e identificadas as espécies de FMAs e, a partir do primeiro mês, avaliou-se a taxa de colonização das raízes da braquiária. Os inoculantes produzidos apresentaram diferenças no número de esporos e espécies, nas espécies de FMAs identificadas e na taxa de colonização das raízes, dependendo da cobertura florestal. Assim, considerando o aumento no número de esporos, espécies e colonização ao longo do tempo, o inoculante produzido a partir do solo da Mata Nativa apresentou-se mais promissor para o uso.

Palavras-chave: simbionte; vaso armadilha; recuperação florestal.

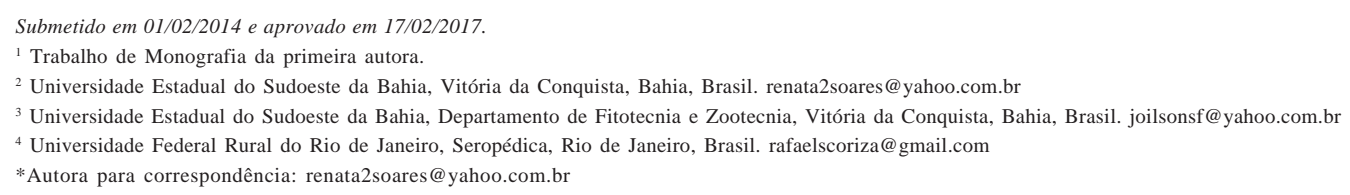




\section{INTRODUCTION}

The demand for food, renewable fuels and fibers has been growing to meet the world's population growth. There is also a great deal of concern about protecting and restoring forests. However, one of the great problems in Brazil is the low natural fertility of most of soils, which drives the search for sustainable solutions, including the use of soil microorganisms such as arbuscular mycorrhizal fungi, which have proven promising in facilitating nutrient availability and uptake by the plants (Burity, 2000; Lopes et al., 2007; Carneiro et al., 2012; Carvalhães, 2013).

Arbuscular mycorrhizal fungi (AMFs) are obligate biotrophic organisms that live with the vast majority of known forest species, such as in the metabolically active roots of terrestrial vascular plants, epiphytes, rhizoids and stems of bryophytes, forming a symbiotic mutualistic relationship called arbuscular mycorrhiza (Trappe \& Schenck et al., 1982; Linderman, 1994; Moreira \& Siqueira, 2006).

AMFs promote a significant increase of the area of root absorption of plants colonized, maximizing the use of water and nutrients (Smith \& Read, 2008; Stürmer et al., 2009). These fungi enhance plant resistance to water stress, high temperatures, conditions of toxicity and acidity of soil and pathogens (Smith \& Read, 2008), in addition to soil stabilization in the form of aggregates (Daynes et al., 2013, Peng et al., 2013).

Thus the selection and inoculation of mycorrhizal fungi with beneficial functions can contribute to the establishment of seedlings and the recovery of degraded areas, since they accelerate plant development and increase the tolerance to transplant stress and to restoration of nutrient cycling (Souza et al., 2006; Soares \& Carneiro, 2010; Angelini et al., 2013).

In spite of their potential and benefits, the large-scale use of AMFs is still restricted, mainly due to the lack of availability of inoculant in high quantities, low cost and high quality, besides the lack of practicality of inoculation in the field (Souza et al. 2006; Miranda, 2008; Ijdo et al., 2011). Their efficiency is also questioned by Paluch et al. (2013), who argue that the native community of mycorrhizal fungi promotes greater root colonization than the addition of commercial inoculants.

In addition to this monosporic inoculant, it is possible to produce inoculant with different native species with greater ease and speed (Lambert et al., 1980; Hayman, 1982). In comparison with the commercial inoculant, it has a low cost, higher taxonomic diversity, and the use of locally adapted species (Schwartz et al., 2006; Douds Jr. et al., 2010), which increases the chances of positive effects on the plant (Klironomos, 2003) and avoid the introduction of exotic species (Ijdo et al., 2011). The use of AMF inoculant produced from the forest soil is the most reliable and recommended method because of its high species diversity, the potential to accelerate the ecological restoration of the soil environment and to promote the germination and growth of the plants (Klironomos, 2003; Huante et al., 2012; Paluch et al., 2013).

Therefore, the objective of this study was to evaluate the production of native AMF inoculants from soils under different forest covers in Vitória da Conquista, BA, by means of the quantification of spores, species identification and rate of root colonization.

\section{MATERIAL AND METHODS}

\section{Area of study and soil collection}

The study was carried out in the city of Vitória da Conquista (BA) located at $891 \mathrm{~m}$ altitude. The climate of the region is of type Aw, according to classification of Köppen. The soil is classified as Dystrophic Yellow Latosol (Embrapa, 2013).

Three different forest covers were used in the study: a native forest fragment (Montana Semi-deciduous Forest), a seven-year-old plantation of Madeira Nova (Pterogyne nitens Tull. (Fabaceae - Caesalpinioidae)), and a five-yearold plantation of eucalyptus (Eucalyptus urophylla S. T. Blake (Myrtaceae)). The fragment has a considerable total area in intermediate stage of regeneration, according to the criteria of CONAMA resolution no. 1 of 1994. It is a forest with relatively low stand height (tree height between 10 and $15 \mathrm{~m}$ ) composed of partially deciduous mesophanerophytes, colonized by lianas, with predominance of ecotypes of the family Leguminosae, standing out the genus Parapiptadenia.

Four plots of $21 \times 21 \mathrm{~m}$ were delineated at each site, in which four simple samples of soil per plot were collected randomly in 2011 , at depth of $0-5 \mathrm{~cm}$. This depth was chosen based on the methodology proposed by other authors and due to the highest occurrence of spores in this soil layer (Silva et al., 2006; Angelini et al., 2012).

\section{Assembling the experiment}

The discrete samples were mixed together to create one composite sample per plot, then, $100 \mathrm{~g}$ of each sample was taken for chemical analysis and $50 \mathrm{~g}$ for spore extraction and species identification. The rest of the sample was distributed into five pots (500 $\mathrm{mL}$ disposable cups) which were sown with Brachiaria sp., aiming to multiply and restore infective structures of the AMF species present in the trap cultures (adaptation of Stutz \& Morton protocols, 1996), and kept in a greenhouse of the Universidade Estadual do Sudoeste da Bahia. The experiment was carried out in a completely randomized design. At each month, one pot of each plot was taken for analysis, using $50 \mathrm{~g}$ of 
soil for spore extraction and AMF identification and the roots for evaluation of the mycorrhizal colonization rate.

The experiment was terminated at five months after the germination of the brachiaria seeds in all the pots. Six treatments (control (pot without plants), $1^{\text {st }}$ month, $2^{\text {nd }}$ month, $3^{\text {rd }}$ month, $4^{\text {th }}$ month and $5^{\text {th }}$ month) were analyzed with four replicates from each site studied (plots), except for the mycorrhizal colonization rate of roots, for which a control treatment is not possible. To evaluate the chemical changes in the soil throughout the experiment, $25 \mathrm{~g}$ of soil was taken from each replication of the $5^{\text {th }}$ month treatment and sent for chemical analysis to determine $\mathrm{pH}$, organic matter, Phosphorus $(\mathrm{P})$, Hydrogen + Aluminum $(\mathrm{H}+\mathrm{Al})$, Potassium (K), Calcium (Ca), Magnesium (Mg), Base Saturation (V) and Aluminum Saturation (m).

\section{Quantification and identification of AMFs}

The extraction and identification of the spores and the evaluation of the root colonization rate were carried out at the Laboratório de Micorrizas (Laboratory of Mycorrhizae) at Embrapa Agrobiologia. The spores were extracted from samples of $50 \mathrm{~g}$ of soil of each treatment using the modified wet sieving method (Gerdemann \& Nicolson, 1963) and density gradient centrifugation for separating nematodes from soil (Jenkins, 1964).

Spores were counted by pouring the whole processed sample into a channeled Petri dish, under a $32 \mathrm{X}$ stereoscopic microscope, and the results were expressed as number of spores per gram. Later, the spores were grouped by size, color and shape characteristics, and placed on slides with polyvinyl alcohol in lactoglycerol (PVLG) under a coverslip. In the same slide a second set of spores was subjected to a mixture of PVLG + Melzer Reagent (1:1).

The spores, under both coverslips, were mechanically broken to expose the inner walls (when present). The color reaction to the Melzer reagent was used to characterize spore walls. The AMF species identification was performed according to Schenck \& Pérez (1988) and published descriptions of the identified species, as well as searches to websites of international culture collections of AMFs (http:/ /invam.caf.wvu.edu/ and http: // www.mycobank.org).

To evaluate mycorrhizal colonization, the roots were washed, clarified and stained using the methodology of Philips \& Hayman (1970) modified by Koske \& Gemma (1989) and Grace \& Stribley (1991). The percentage of fungal structures in the root was determined by the Gridline Intersect Method described by Newman (1966) and modified by Giovannetti \& Mosse (1980), in which a sample of root fragments was spread in a $1 / 2$-inch gridded Petri dish and examined under a stereoscopic microscope.

A total of 100 root fragments were examined crossing the lines of the grid in each sample for presence or absence of colonization. The total of fragments with presence of colonization was transformed into percentage based on the total of segments examined.

\section{Data analysis}

The frequency of the identified species (for each site and month) was calculated by the equation $\mathrm{Fi}=\mathrm{Ji} / \mathrm{K}$, where $\mathrm{Fi}$ is the frequency of species $\mathrm{i}$; Ji is the number of samples in which species $\mathrm{i}$ occurred and $\mathrm{K}$ is the total number of soil samples (Brower et al., 1990).

Data were submitted to Lilliefors and Cochran and Bartlett tests to verify normality and homogeneity of variances, respectively, using the software SAEG® ${ }^{\circledR}$ v.9.1 (Euclides, 2007). Since the data were parametric, the analysis of variance was used for grouping the treatments within the same month and the Scott-Knott Test was applied at $5 \%$ probability with the software SISVAR ${ }^{\circledR}$ v.5.3 (Ferreira, 2007). The evaluation over the months was based on the regression curve calculated with the Microsoft Office Excel 2007 and the significance of the curve was tested by the software SISVAR $®$ V.5.3, considering a significance of $5 \%$ (Ferreira, 2007).

\section{RESULTS AND DISCUSSION}

In the process for producing the inoculants from soils under different forest covers, there were changes in the number of spores, number and composition of species and percentage of root colonization in the AMF community during the months evaluated.

The number of spores in the soils from the three forest covers was different during the production of the inoculants. The soil under Madeira Nova had the greatest amount of spores in all months evaluated. The regression was significant only for the site of native forest, with a trend of increasing the number of spores over time (Figure 1).

Bagyaraj \& Stürmer (2010) discussed that one way to favor sporulation for the production of inoculants from native soils is the use of the trap culture, as it was performed in this study, since it provides young and healthy spores. However, this was not verified for the AMFs from the soils under Madeira Nova and eucalyptus, which may be associated with the difference in the vegetation cover, directly affecting the variability and multiplication of the fungi (Sieverding, 1991).

The number of AMF species was similar among the sites, showing difference only in the $3^{\text {rd }}$ month for the area of native forest, which was lower than the areas of Madeira Nova and Eucalyptus. The regression was significant only for the covers of native forest and Madeira Nova, showing a trend of increase over time (Figure 2).

According to Miranda (2008), the diversity of species of arbuscular mycorrhizal fungi present in a soil should be 
evaluated using fresh spores isolated from trap cultures, which explains the increase in the number of species in the sites of native forest and Madeira Nova.

The regression curve for root colonization rate in the soils from the three sites showed a trend of increasing over time. Among the sites, there was difference for the same month and in the $5^{\text {th }}$ month the colonization of the soil under Madeira Nova was greater than the others (Figure 3).

\section{Native Forest}

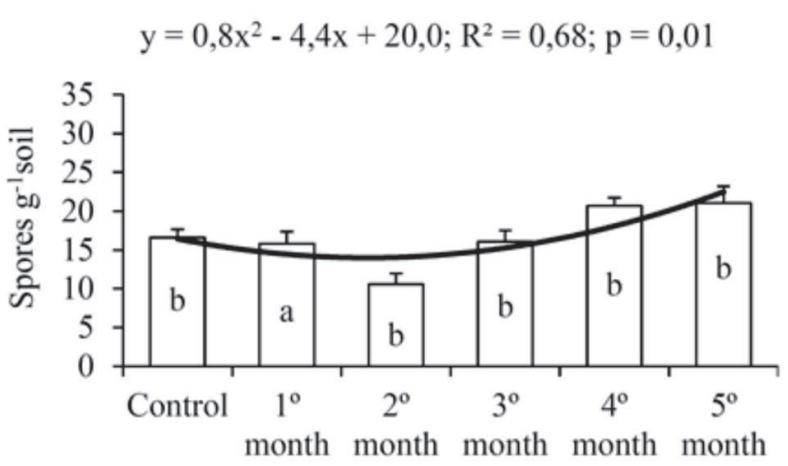

Madeira Nova

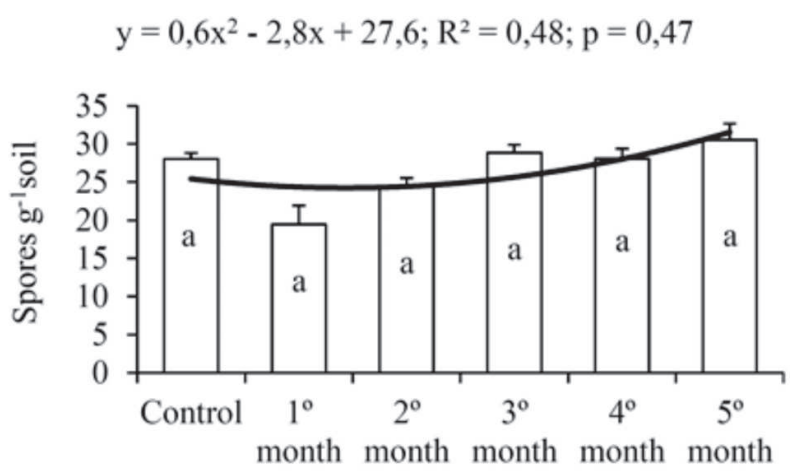

Eucalyptus

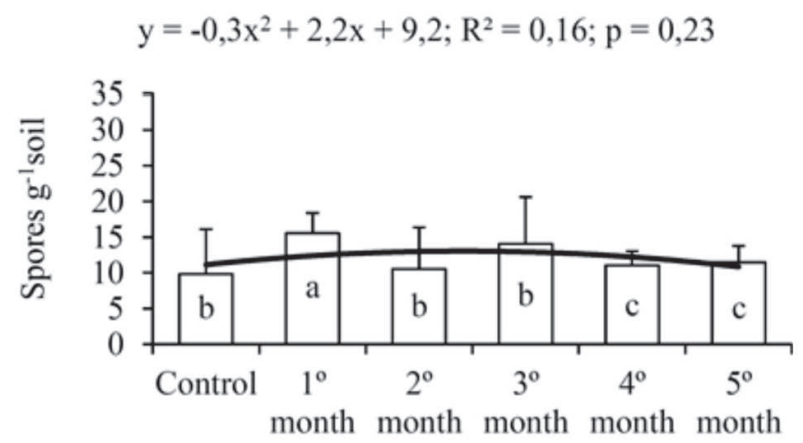

Figure 1: Number of AMF spores in the soils under forest covers in Vitória da Conquista (BA) and respective regression curve throughout the months of inoculant production. At each month, sites followed by the same letters belong to the same group by the Scott-Knott test $(\mathrm{p}=0.05)$.
Although the number of spores did not increase in some sites (Figure 1), the results of the colonization confirm the presence of infective propagules such as hyphae, roots and substrates infected, which can also be used as inoculants (Miranda, 2008) and can show higher infectivity than spores in suspension (Sieverding, 1991; Schreiner et al., 2007). For this reason, species native to the soil or the site have been considered as more effective mutualists than non-native fungi.
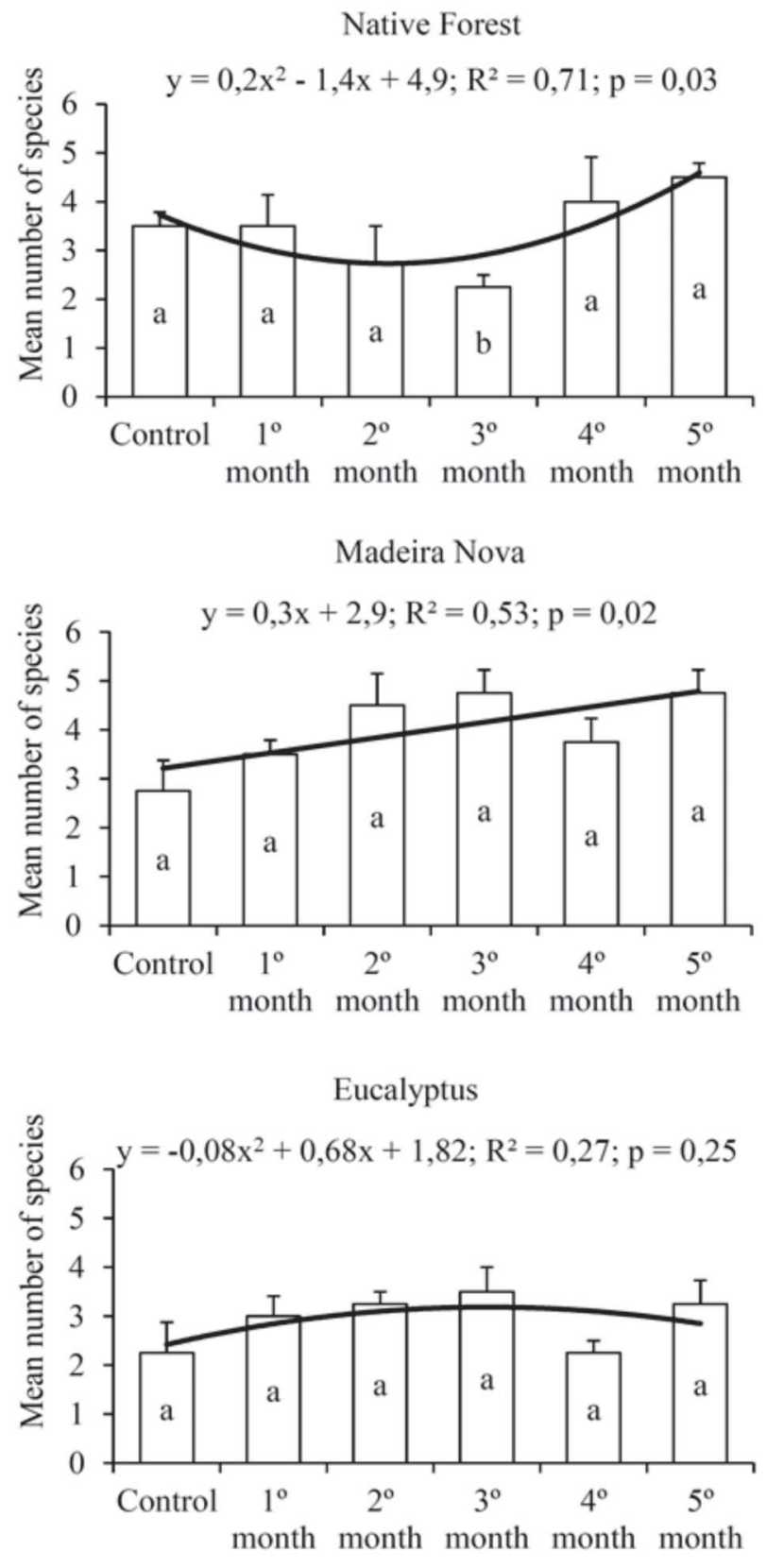

Figure 2: Mean number of AMF species in the soils under forest covers in Vitória da Conquista (BA) and respective regression curve throughout the months of inoculant production. At each month, sites followed by the same letters belong to the same group by the Scott-Knott test $(\mathrm{p}=0.05)$. 
Thus, in general, only the community from soil of the native forest showed increase both in species diversity and fungal structures that can be used as inoculants (spores and colonized roots). The community in this forest
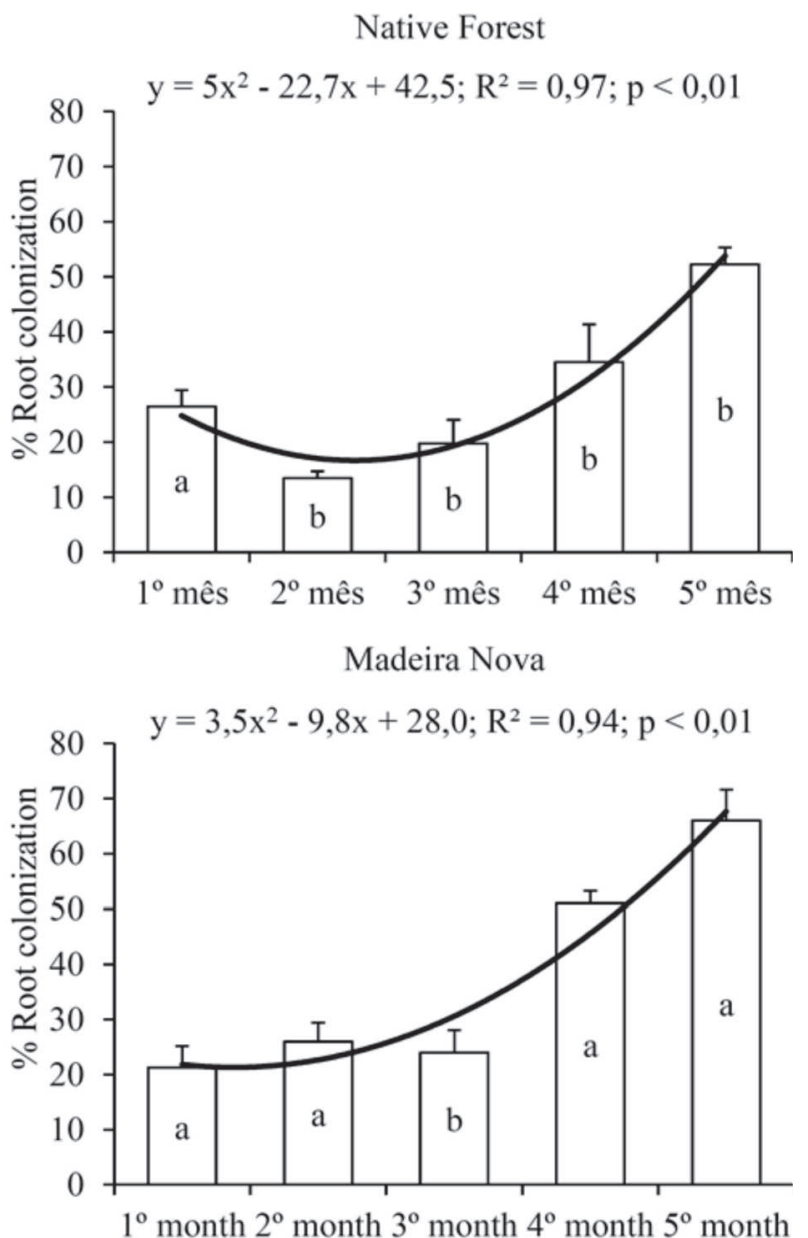

Eucalyptus

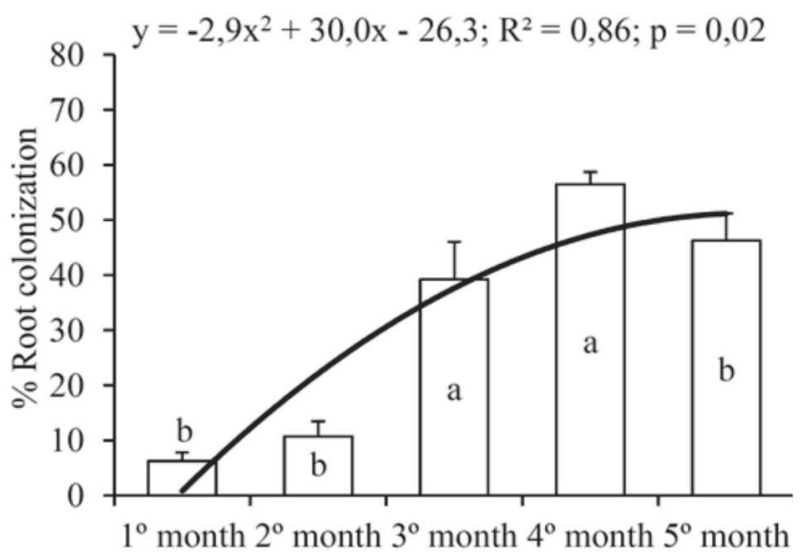

Figure 3: Percentage of AMF colonization in the roots of brachiaria in the soils under forest covers in Vitória da Conquista (BA) and respective regression curve throughout the months of inoculant production. At each month, sites followed by the same letters belong to the same group by the Scott-Knott test $(\mathrm{p}=0.05)$. cover was also the only one to have a significant relation of colonization rate with the number of spores and number of species (Table 1).

The different correlations found for inoculant production in the studied sites reflect the several biotic and abiotic factors that regulate the occurrence of these fungi, interfering in the survival and germination of infective propagules and changing the effect and the process of root colonization in plants (Cardoso et al., 2010). Among these factors are the amount and composition of mycorrhizal fungi and the presence of other microorganisms in the soil (Zangaro et al., 2000).

The soil from the three forest covers had the total number of species (identified by the spores) increased during the 5 months, in which the native forest showed the greatest diversity of species (16), following Madeira Nova with 11 species and Eucalyptus with 10 species. The species Acaulospora laevis, Acaulospora mellea, Acaulospora scrobiculata, Ambispora leptoticha, Diversispora tortuosa, Gigaspora sp. and Glomus macrocarpum were found in the three sites. Four species occurred only in the cover of native forest, two species in Eucalyptus, and all species in Madeira Nova were present in one of the other covers (Table 2).

Comparing the occurrence of AMF species, there were changes along the production of inoculants, both in relation to the number of species identified and their frequency. Some species such as Acaulospora laevis, Rhizophagus clarus and others were present in the control and showed variation of occurrence in the form of spores throughout the inoculant production. The species Glomus glomerulatum, Glomus microaggregatum and other seven were not found in the control and were identified throughout the experiment. It is noteworthy that the species Ambispora leptoticha and Glomus macrocarpum occurred in all forest covers and treatments, with the former showing $100 \%$ of frequency.

The use of the trap culture provided a means of investigating the AMF diversity in the sites studied, since it identified species that were not sporulating in the field at the time of sampling (Bagyaraj \& Stürmer, 2010), as shown in Table 2, and facilitated the determination of the frequency of species over time.

In general, the activity of mycorrhizal fungi and the association with roots of higher plants during the year are subject to variations in temperature, humidity, soil organic matter, phosphorus, nitrogen, $\mathrm{pH}$ and soil aeration (Mello et al., 2006). Nagahashi \& Douds (2007) reported that the highest rates of mycorrhizal colonization occurred in the absence or at low levels of phosphate fertilization. However, Lima et al. (2013) found that spore density and mycorrhizal colonization had no significant correlation with $\mathrm{pH}$ and levels of $\mathrm{K}, \mathrm{Ca}, \mathrm{Mg}, \mathrm{Al}$ and organic matter of the soil, but 
Table 1: Correlation between number of spores, number of species and rate of colonization of AMFs present in the soils of the study sites in Vitória da Conquista, BA

\begin{tabular}{lccc}
\hline Pearson Correlation & NS X NP & NS X CR & NP X CR \\
\hline Native Forest & 0.43 & $0.71^{* *}$ & $0.48^{*}$ \\
Madeira Nova & 0.21 & 0.21 & 0.09 \\
Eucalyptus & 0.10 & -0.13 & -0.22 \\
\hline
\end{tabular}

NS = Number of spores; NP = Number of species; CR = Colonization Rate. Significant at $1 \%(* *)$ and $5 \%(*)$.

Table 2: Frequency of occurrence of AMF species in the soils under forest covers in Vitória da Conquista (BA) at the study site (T) and throughout the production of the inoculant

\begin{tabular}{|c|c|c|c|c|c|c|}
\hline \multirow{2}{*}{ Species } & $\mathbf{T}$ & 1 & 2 & 3 & 4 & 5 \\
\hline & \multicolumn{6}{|c|}{ Frequency $(\%)$} \\
\hline \multicolumn{7}{|l|}{ NATIVE FOREST } \\
\hline A. foveata Trappe \& Janos & 50 & 0 & 0 & 25 & 0 & 0 \\
\hline A. laevis Gerdemann \& Trappe & 50 & 0 & 0 & 0 & 25 & 0 \\
\hline A. mellea Spain \& Schenck & 25 & 0 & 0 & 0 & 50 & 25 \\
\hline A. rehmii Sieverding \& Toro & 0 & 25 & 0 & 0 & 0 & 25 \\
\hline A. scrobiculata Trappe & 50 & 0 & 0 & 0 & 50 & 50 \\
\hline A. tuberculata Janos \& Trappe. & 0 & 25 & 25 & 0 & 25 & 0 \\
\hline Ambispora leptoticha (N.C. Schenck \& G.S. Sm.) C. Walker, Vestberg \& A. Schüssler & 25 & 50 & 50 & 50 & 25 & 100 \\
\hline Claroideoglomus lamellosum (Dalpé, Koske \& Tews) C. Walker \& A. Schüßler & 0 & 0 & 0 & 25 & 0 & 0 \\
\hline Diversispora tortuosa Schenck \& Smith & 0 & 25 & 25 & 0 & 0 & 0 \\
\hline G. glomerulatum Sieverding & 0 & 25 & 25 & 0 & 0 & 0 \\
\hline G. macrocarpum Tulasne \& Tulasne & 100 & 100 & 100 & 100 & 100 & 100 \\
\hline G. microaggregatum Koske, Gemma \& Olexia & 0 & 50 & 0 & 0 & 0 & 0 \\
\hline Gigaspora sp. & 25 & 0 & 25 & 0 & 75 & 75 \\
\hline Racocetra persica (Koske \& C. Walker) Oehl, F.A. Souza \& Sieverd & 0 & 50 & 0 & 25 & 50 & 75 \\
\hline Rhizophagus clarus (T.H. Nicolson \& N.C. Schenck) C. Walker \& A. Schüßler & 25 & 0 & 0 & 0 & 0 & 0 \\
\hline Scutellospora sp. & 0 & 0 & 25 & 0 & 0 & 0 \\
\hline
\end{tabular}

Scutellospora sp.

MADEIRA NOVA

\begin{tabular}{|c|c|c|c|c|c|c|}
\hline A. foveata Trappe \& Janos & 0 & 0 & 0 & 50 & 0 & 0 \\
\hline A. laevis Gerdemann \& Trappe & 0 & 25 & 75 & 25 & 0 & 50 \\
\hline A. mellea Spain \& Schenck & 25 & 75 & 25 & 75 & 50 & 50 \\
\hline A. scrobiculata Trappe & 50 & 50 & 50 & 100 & 100 & 100 \\
\hline A. tuberculata Janos \& Trappe. & 0 & 0 & 0 & 0 & 25 & 0 \\
\hline Ambispora leptoticha (N.C. Schenck \& G.S. Sm.) C. Walker, Vestberg \& A. Schüssler & 75 & 100 & 100 & 100 & 100 & 100 \\
\hline Claroideoglomus lamellosum (Dalpé, Koske \& Tews) C. Walker \& A. Schüßler & 0 & 0 & 0 & 25 & 0 & 0 \\
\hline Diversispora tortuosa Schenck \& Smith & 25 & 0 & 50 & 0 & 0 & 75 \\
\hline G. glomerulatum Sieverding & 0 & 0 & 25 & 0 & 0 & 0 \\
\hline G. macrocarpum Tulasne \& Tulasne & 100 & 100 & 100 & 100 & 100 & 100 \\
\hline Gigaspora sp. & 0 & 0 & 25 & 0 & 0 & 0 \\
\hline \multicolumn{7}{|l|}{ EUCALYPTUS } \\
\hline A. laevis Gerdemann \& Trappe & 50 & 0 & 25 & 0 & 25 & 25 \\
\hline A. mellea Spain \& Schenck & 0 & 50 & 25 & 100 & 0 & 0 \\
\hline A. scrobiculata Trappe & 25 & 0 & 25 & 75 & 0 & 50 \\
\hline Ambispora leptoticha (N.C. Schenck \& G.S. Sm.) C. Walker, Vestberg \& A. Schüssler & 50 & 75 & 100 & 75 & 100 & 25 \\
\hline Claroideoglomus etunicatum (W.N. Becker \& Gerd.) C. Walker \& A. Schüßler & 0 & 25 & 0 & 0 & 0 & 0 \\
\hline Diversispora tortuosa Schenck \& Smith & 0 & 0 & 25 & 0 & 0 & 100 \\
\hline G. clavisporum (Trappe) Almeida \& Schenck & 0 & 50 & 0 & 0 & 0 & 0 \\
\hline G. macrocarpum Tulasne \& Tulasne & 100 & 100 & 100 & 100 & 100 & 100 \\
\hline G. microaggregatum Koske, Gemma \& Olexia & 0 & 0 & 25 & 0 & 0 & 0 \\
\hline Gigaspora sp. & 0 & 0 & 0 & 0 & 0 & 25 \\
\hline
\end{tabular}

Rev. Ceres, Viçosa, v. 64, n.2, p. 197-204, mar/abr, 2017 
Table 3: Soil chemical properties of the study sites in Vitória da Conquista (BA) and at the $5^{\text {th }}$ month of inoculant production

\begin{tabular}{|c|c|c|c|c|c|c|c|c|c|}
\hline \multirow{2}{*}{ Cover } & \multirow{2}{*}{$\begin{array}{c}\mathrm{pH} \\
\left(\mathrm{H}_{2} \mathrm{O}\right)\end{array}$} & \multirow{2}{*}{$\begin{array}{c}\text { MO } \\
\text { g.dm }^{-3}\end{array}$} & \multirow{2}{*}{$\begin{array}{c}P \\
\text { mg.dm-3 }\end{array}$} & $\mathrm{H}+\mathrm{Al}$ & $\mathbf{K}$ & $\mathrm{Ca}$ & Mg & $\mathbf{V}$ & $\mathbf{m}$ \\
\hline & & & & \multicolumn{4}{|c|}{$\mathrm{cmol}_{\mathrm{c}} \cdot \mathrm{dm}^{-3}$} & \multicolumn{2}{|c|}{$\%$} \\
\hline \multicolumn{10}{|c|}{ Control } \\
\hline Native Forest & 4.0 & 61.3 & 2.5 & 12.6 & 0.24 & 2.4 & 1.3 & 24.0 & 24.0 \\
\hline Madeira nova & 5.2 & 22.5 & 2.3 & 2.7 & 0.25 & 1.8 & 1.4 & 56.5 & 2.8 \\
\hline Eucalyptus & 4.5 & 28.3 & 1.8 & 7.1 & 0.13 & 0.7 & 0.7 & 18.0 & 39.8 \\
\hline \multicolumn{10}{|c|}{$5^{\text {th }}$ month } \\
\hline Native Forest & 4.4 & 71.0 & 2.0 & 11.5 & 0.10 & 2.3 & 0.8 & 22.0 & 26.0 \\
\hline Madeira nova & 5.7 & 26.0 & 1.0 & 2.6 & 0.10 & 1.7 & 1.4 & 55.0 & 3.0 \\
\hline Eucalyptus & 4.7 & 29.0 & 2.0 & 7.2 & 0.10 & 0.8 & 0.7 & 18.0 & 41.0 \\
\hline
\end{tabular}

$\mathrm{V}=$ Base Saturation; $\mathrm{M}=$ Aluminum Saturation.

were significant only with the content of P. Table 3 shows the results of the chemical analysis for the soils of the study sites and after five months of spore production.

However, no significant relationships were found when correlating the chemical characteristics of the soil with the number of spores, species diversity and mycorrhizal colonization, indicating that the results found in this study were predominantly determined by the soil covers from where the AMFs were collected.

\section{CONCLUSIONS}

The inoculants produced showed differences in the number of spores, species and root colonization rate as a function of the forest cover.

Considering the increase in the number of spores, species and colonization over time, the inoculant produced from the soil under the native forest was the most promising for utilization in inoculations.

\section{REFERENCES}

Angelini GAR, Loss A, Pereira MG, Torres JLR \& Saggin Júnior OJ (2012) Colonização micorrízica, densidade de esporos e diversidade de fungos micorrízicos arbusculares em solo de Cerrado sob plantio direto e convencional. Semina: Ciências Agrárias, 33:115-130.

Angelini GAR, Saggin Júnior OJ \& Silva EMR (2013) Seleção de fungos micorrízicos arbusculares e ectomicorrízicos para simbioses eficientes com Acacia mangium willd. Semina: Ciências Agrárias, 34:3529-3542.

Bagyaraj JD \& Stürmer SL (2010) Fungos micorrízicos arbusculares (FMAs). In: Moreira FMS, Huising EJ \& Bignell DE (Eds.) Manual de biologia dos solos tropicais: Amostragem e caracterização da biodiversidade. Lavras, UFLA. p.205-226.

Brower JE, Zar JH \& Von Ende CN (1990) Field and laboratory methods for general ecology. $3^{\text {rd }}$ ed. Dubuque, W. C. Brown. $237 p$.

Burity HA, Lyra MCCP, Souza ES, Mergulhão ACES \& Silva MLRB (2000) Efetividade da inoculação com rizóbio e fungos micorrízicos arbusculares em mudas de sabiá submetidas a diferentes níveis de fósforo. Pesquisa Agropecuária Brasileira, 35:801-807.
Cardoso EJBN, Cardoso IM, Nogueira MA, Baretta CRDM \& Paula MA (2010) Micorrizas arbusculares na aquisição de nutrientes pelas plantas. In: Siqueira JO, Souza FA, Cardoso EJBN \& Tsai SM (Eds.) Micorrizas: 30 anos de pesquisa no Brasil. Lavras, Editora UFLA. p.153-214.

Carneiro RFV, Cardozo Júnior FM, Pereira LF, Araújo ASF \& Silva GA (2012) Fungos micorrízicos arbusculares como indicadores da recuperação de áreas degradadas no Nordeste do Brasil. Revista Ciência Agronômica, 43:648-657.

Carvalhães E (2013) O desafio dos 4 Fs. Revista O Papel, p. 17.

Daynes CN, Field DJ, Saleeba JA, Cole MA \& McGee PA (2013) Development and stabilization of soil structure via interactions between organic matter, arbuscular mycorrhizal fungi and plant roots. Soil Biology \& Biochemistry, 57:683-694.

Douds Jr. DD, Nagahashi G \& Hepperly PR (2010) On-farm production of inoculum of indigenous arbuscular mycorrhizal fungi and assessment of diluentes of compost for inoculum production. Bioresource Technology, 101:2326-2330.

Embrapa - Empresa Brasileira de Pesquisa Agropecuária (2013) Sistema Brasileiro de Classificação de solos. $3^{\text {a }}$ ed. Rio de Janeiro, Embrapa. 353p.

Euclides RF (2007) SAEG - Sistema para análises estatísticas, versão 9.1. Viçosa, FUNARBE. Disponível em: <http:// www.ufv.br/saeg/>. Acessado em: 04 de maio de 2013.

Ferreira DF (2007) Sisvar, versão 5.3. Lavras, DEX/UFLA. Disponível em: <http://www.dex.ufla.br/ danielff/softwares.htm>. Acessado em: 27 de abril de 2012.

Gerdemann JW \& Nicolson TH (1963) Spores of mycorrhizal endogone species extracted from soil by wet-sieving and decanting. Transactions of British Mycological Society, 46:235244.

Giovannetti M \& Mosse B (1980) An evaluation of techniques to measure vesicular-arbuscular mycorrhizal infection in roots. The New Phytologist, 84:484-500.

Grace C \& Stribley DP (1991) A safer procedure for routine staining of vesicular-arbuscular mycorrhizal fungi. Mycological Research, 95:1160-1162.

Hayman DS (1982) Practical aspects of vesicular-arbuscular mycorrhiza. In: Subbarao NS (Ed.) Advances in agricultural microbiology. London, Butterworth-Heinemann. p.325-373.

Huante P, Ceccon E, Orozco-Segovia A, Sánchez-Coronado ME, Acosta I \& Rincón E (2012) The role of arbuscular mycorrhizal fungi on the early-stage restoration of seasonally dry tropical forest in Chamela, Mexico. Revista Árvore, 36:279-289. 
Ijdo M, Cranenbrouch S \& Declerck S (2011) Methods for largescale production of AM fungi: past, present, and future Mycorrhiza, 21:01-16.

Jenkins WR (1964) A rapid centrifugal-flotation technique for separating nematodes from soil. Plant Disease Report, 48:692.

Klironomos JN (2003) Variation in plant response to native and exotic arbuscular mycorrhizal fungi. Ecology, 84:2292-2301.

Koske RE \& Gemma JN (1989) A modified procedure for staining roots to detect VA mycorrhizas. Mycological Research, 92:486488 .

Lambert DH, Cole H \& Baker DE (1980) Adaptation of vesiculararbuscular mycorrhizae to edaphic factors. New Phytologist, 25:513-520.

Lima FS, Soares ACF \& Souza CS (2013) Ocorrência e atividade de fungos micorrízicos arbusculares em plantios de Eucalipto (Eucalyptus sp.) no litoral norte da Bahia, Brasil. Revista Árvore, 37:245-255.

Linderman RG (1994) Role of VAM fungi in biocontrol. In: Pfleger FL \& Linderman RG (Eds.) Mycorrhizae and plant health. St. Paul, APS. p.01-26.

Lopes AS \& Guilherme LRG (2007) Fertilidade do solo e produtividade agrícola. In: Novais RF, Alvarez VVH, Barros NF, Fontes RLF, Cantarutti RB \& Neves JCL (Eds.). Fertilidade do solo. Viçosa, SBCS. p.1-64

Mello AH, Antoniolli ZI, Kaminski J, Souza EL \& Oliveira VL (2006) Fungos arbusculares e ectomicorrízicos em áreas de eucalipto e de campo nativo em solo arenoso. Ciência Florestal, 16:291-301.

Miranda JCC (2008) Cerrado: micorriza arbuscular - ocorrência e manejo. Planaltina, Embrapa Cerrados. 169p.

Moreira FMS \& Siqueira JO (2006) Microbiologia e Bioquímica do Solo, $2^{\mathrm{a}}$ ed. Lavras, Editora UFLA. 729p.

Nagahashi G \& Douds DJ (2007) Separated components of root exudate and cytosol stimulate different morphologically identifiable types of branching responses by arbuscular mycorrhizal fungi. Mycological research, 3:487-492.

Newman EJ (1966) A method of estimating the total length of root sample. Journal of Applied Ecology, 3:139-145.

Paluch ES, Thomsen MA \& Volk T (2013) Effects of resident soil fungi and land use history outweigh those of comercial mycorrhizal inocula: testing a restoration strategy in unsterilized soil. Restoration Ecology, 21:380-389.

Peng S, Guo T \& Liu G (2013) The effects of arbuscular mycorrhizal hyphal networks on soil aggregations of purple soil in southwest China. Soil Biology \& Biochemistry, 57:411-417.
Philips JM \& Hayman DS (1970) Improved procedure for clearing roots and staining parasitic and vesicular-arbuscular mycorrhizal fungi for rapid assessment of infection. Transaction of the British Mycological Society, 55:158-161.

Schenck NC \& Perez Y (1988) A manual of identification of vesicular-arbuscular mycorrhizal fungi. 2 ed. Gainesville, University of Florida. 241p.

Schreiner RP (2007) Effects of native and nonnative arbuscular mycorrhizal fungi on growth and nutriente uptake of 'Pinot noir' (Vitis vinifera L.) in two soils with contrasting levels of phosphorus. Applied soil ecology, 36:2005-2015.

Schwartz MW, Hoeksema JD, Gehring CA, Johnson NC, Klironomos JN, Abbott LK \& Pringle A (2006) The promise and the potential consequences of the global transport of mycorrhizal fungal inoculum. Ecology Letters, 9:501-515.

Sieverding E (1991) Stablishment and evaluation of VAM fungal germ plasm. In: Sieverding E (Ed.) Vesicular-arbuscular mycorrhiza management. Eschoborn, GTZ. p.189-219.

Silva CF, Pereira MG, Silva EMR, Correia MEF \& Saggin Júnior OJ (2006) Fungos micorrízicos arbusculares em áreas no entorno do Parque Estadual da Serra do Mar em Ubatuba (SP). Caatinga, 19:01-10.

Smith SE \& Read DJ (2008) Mycorrhizal symbiosis. London, Academic Press. 787p.

Soares CRFS \& Carneiro MAC (2010) Micorrizas arbusculares na recuperação de áreas degradadas. In: Siqueira JO, Souza FA, Cardoso EJBN \& Tsai SM (Eds.) Micorrizas: 30 anos de Pesquisa no Brasil. Lavras, Editora UFLA. p.441-474.

Souza VC, Silva RA, Cardoso G \& Barreto AF (2006) Estudo sobre fungos micorrízicos. Revista Brasileira de Engenharia Agrícola e Ambiental, 10:612-618.

Stürmer SL, Cardoso EJBN, Souza FA \& Kasuya MCM (2009) "Além das raízes": o papel dos fungos micorrízicos. Viçosa, SBCS. p.30-32.

Stutz JC \& Morton JB (1996) Sucessive pot cultures reveal high species richness of arbuscular endomycorrhizal fungi in arid ecosystems. Canadian Journal of Botany, 74:1883-1889.

Trappe JM \& Schenck NC (1982) Vesicular-arbuscular mycorrhizal fungi (Endogonales). In: Schenck NC (Ed.) Methods and Principles of Micorrhizal Research. St. Paul, The American Phytopathological Society. p.01-09.

Zangaro W, Bononi VLR \& Trufen SB (2000) Mycorrhizal dependency, inoculum potential and habitat preference of native woody species in South Brazil. Journal of Tropical Ecology, 16:603-622. 